\title{
Characterization of Isomeric Cationic Porphyrins with $\beta$-Pyrrolic Substituents by Electrospray Mass Spectrometry: The Singular Behavior of a Potential Virus Photoinactivator
}

\author{
Raul A. Izquierdo, Cristina M. Barros, M. Graça Santana-Marques, \\ and A. J. Ferrer-Correia \\ Mass Spectrometry Laboratory, Department of Chemistry, University of Aveiro, Campus de Santiago, \\ Aveiro, Portugal \\ Eduarda M. P. Silva, Francesca Giuntini, Maria A. F. Faustino, \\ João P. C. Tomé, Augusto C. Tomé, Artur M. S. Silva, \\ Graça P. M. S. Neves, \\ and J. A. S. Cavaleiro \\ Organic Chemistry Laboratory, Department of Chemistry, University of Aveiro, Campus de Santiago, \\ Aveiro, Portugal
}

Andreia F. Peixoto, Mariette M. Pereira, and Alberto A. C. C. Pais

Department of Chemistry, University of Coimbra, Coimbra, Portugal

Electrospray ionization mass spectrometry (ESI-MS) and tandem mass spectrometry (ESI-MS/ MS) have been used to differentiate the 2- and 4-methylpyridyl isomers of free-base and metallated cationic $\beta$-vinylpyridylporphyrins. The analysis by ESI-MS/MS of the deuterated analogs and semiempirical calculations of structural and electronic parameters were also undertaken. The two free-base isomers are easily differentiated by ESI-MS/MS but the presence of a metallic center renders differentiation of the metallated isomers less effective. The data acquired show that of all the studied compounds, the free-base 2-methylpyridyl isomer, which was operative in the in vitro photoinactivation of Herpes simples virus, has a different gas-phase behavior. Local distortion of the macrocycle due to the presence of the $\beta$-vinylpyridyl substituent occurs for all the compounds, but a different electron density distribution can account for the observed gas-phase behavior of this potential virus photoinactivator. (J Am Soc Mass Spectrom 2007, 18, 218-225) (C) 2007 American Society for Mass Spectrometry

$\mathrm{P}$ orphyrins have a wide range of applications, especially in medicine, where several porphyrins are currently used as photosensitizers in photodynamic therapy (PDT) $[1,2]$. Porphyrins can also be very effective in the photodynamic inactivation of microorganisms through a technique called photodynamic antimicrobial chemotherapy (PACT) [3, 4].

Viruses are responsible for a large number of infectious diseases. In particular, the Herpes simplex virus is one of the most common agents responsible for viral

Published online October 27, 2006

Address reprint requests to Dr. M. G. Santana-Marques, Mass Spectrometry Laboratory, Department of Chemistry, University of Aveiro, Campus de Santiago, 3810-193 Aveiro, Portugal. E-mail grmarques@dq.ua.p infections in man [5]. From preliminary virus inactivation studies carried out with Herpes simplex virus type 1 (HSV-1) using the cationic porphyrins 1 and 2 (Scheme 1), we have observed that despite their structural resemblance and their similar photocytotoxicity profiles, Compound 1 was very effective in the photoinactivation of the virus, whereas Compound 2 displayed no virucidal effect in the same conditions [6].

Electrospray ionization mass spectrometry (ESI-MS) was successfully applied to characterize porphyrins as early as 1991 [7] and both ESI-MS [8-11] and tandem mass spectrometry (ESI-MS/MS) $[12,13]$ have been used to study neutral and cationic porphyrins since then. We wanted to know if the two porphyrin isomers, $\mathbf{1}$ and 2, could be differentiated by ESI-MS/MS and if the informa- 


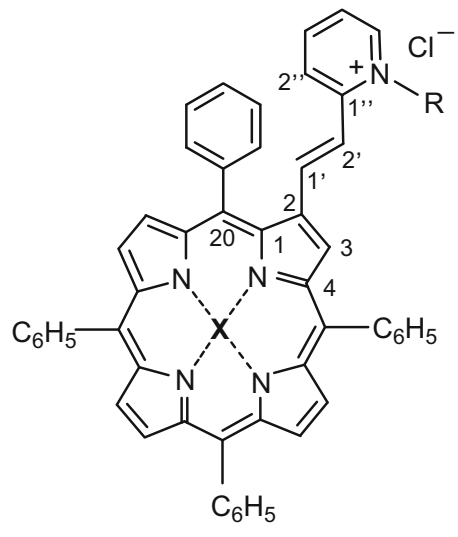

$1 \mathrm{X}=2 \mathrm{H}, \mathrm{R}=\mathrm{CH}_{3}$

$1 \mathrm{Ni} \quad \mathrm{X}=\mathrm{Ni}, \mathrm{R}=\mathrm{CH}_{3}$

1Zn $\mathrm{X}=\mathrm{Zn}, \mathrm{R}=\mathrm{CH}_{3}$

1D $\mathrm{X}=2 \mathrm{H}, \mathrm{R}=\mathrm{CD}_{3}$

1DNi $\mathrm{X}=\mathrm{Ni}, \mathrm{R}=\mathrm{CD}_{3}$

1DZn $\mathrm{X}=\mathrm{Zn} \mathrm{R}=\mathrm{CD}_{3}$

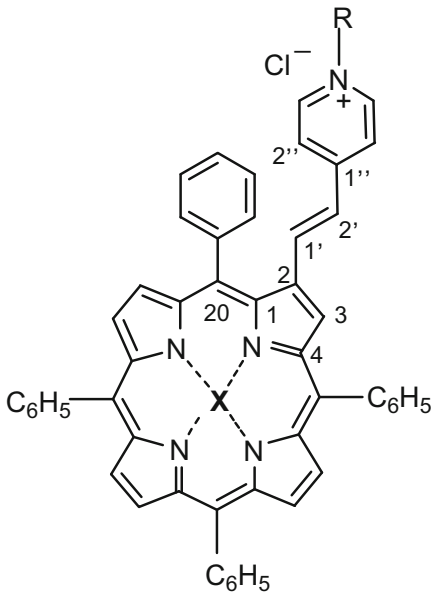

$2 \mathrm{X}=2 \mathrm{H}, \mathrm{R}=\mathrm{CH}_{3}$

2Ni $\mathrm{X}=\mathrm{Ni}, \mathrm{R}=\mathrm{CH}_{3}$

2Zn $\mathrm{X}=\mathrm{Zn} \mathrm{R}=\mathrm{CH}_{3}$

2D $\mathrm{X}=2 \mathrm{H}, \mathrm{R}=\mathrm{CD}_{3}$

2DNi $\mathrm{X}=\mathrm{Ni}, \mathrm{R}=\mathrm{CD}_{3}$

2DZn X $=\mathrm{Zn} \mathrm{R}=\mathrm{CD}_{3}$

Scheme 1

tion obtained on their gas-phase behavior could be relevant to understand their virucidal properties.

The presence of $\beta$-pyrrolic substituents, as well as the presence of metal centers in meso-tetraphenylporphyrins $[14,15]$ can alter the planarity of the porphyrin macrocycle. In the last two decades, the relation between the nonplanarity of several porphyrins and their function in natural systems have been investigated $[16,17]$.

We also wanted to investigate deviations from planarity and the possible influence on the gas-phase fragmentations of the above mentioned $\beta$-vinyl substituted porphyrins. Thus, the aim of the present work was to obtain, by using ESI-MS/MS, as much structural information as possible, not only on the porphyrin isomers as free bases (Compounds $\mathbf{1}$ and 2, Scheme 1), but also on their complexes with two different metals (Compounds 1Ni, 2Ni, 1Zn, and 2Zn, Scheme 1). To substantiate and complement the acquired information, the analysis by ESI-MS/MS of the deuterated analogs, 1D, 1DNi, 1DZn, 2D, 2DNi, and 2DZn, (Scheme 1) and semiempirical calculations of structural and electronic parameters were also undertaken.

The data acquired show that of all the studied compounds, Compound $\mathbf{1}$ and the deuterated analog 1D have a singular gas-phase behavior that can be related to the virucidal effect of the former.

\section{Experimental}

The deuterated and nondeuterated compounds were synthesized as chloride salts $(\mathrm{MCl})$ via a base catalyzed aldol-type condensation process, using 2-formyl5,10,15,20-tetraphenylporphyrin and deuterated and nondeuterated 1,2- and 1,4- dimethylpyridinium iodides. Under these conditions, only the $\mathrm{E}$ isomers are obtained [6]. The ${ }^{\circ}$ compounds $^{\circ}$ were ${ }^{\circ}$ characterized by ${ }^{01} \mathrm{H}$ and ${ }^{13} \mathrm{C}$ nuclear magnetic resonance (NMR), elemental analysis, and ultraviolet-visible (UV-Vis) spectroscopy.

Electrospray mass spectra were acquired with a Micromass Q-TOF 2 (Micromass, Manchester, UK), with a Z-spray source, an electrospray probe, and a syringe pump. Source block and desolvation temperatures were 80 and $150^{\circ} \mathrm{C}$, respectively. The capillary voltage was $3000 \mathrm{~V}$. The instrument was operated at a

Table 1. Compounds and monoisotopic masses of $\mathrm{M}^{+}$ions

\begin{tabular}{lc}
\hline \multicolumn{1}{c}{ Compounds } & $\begin{array}{c}\text { Monoisotopic } \\
\text { mass of } \mathrm{M}^{+} / \mathrm{Da}\end{array}$ \\
\hline \hline 1 and 2 & 732 \\
$1 \mathrm{Ni}$ and $2 \mathrm{Ni}$ & 788 \\
$1 \mathrm{Zn}$ and 2Zn & 794 \\
$1 \mathrm{D}$ and 2D & 735 \\
$1 \mathrm{DNi}$ and 2DNi & 791 \\
$1 \mathrm{DZn}$ and 2DZn & 797 \\
\hline
\end{tabular}




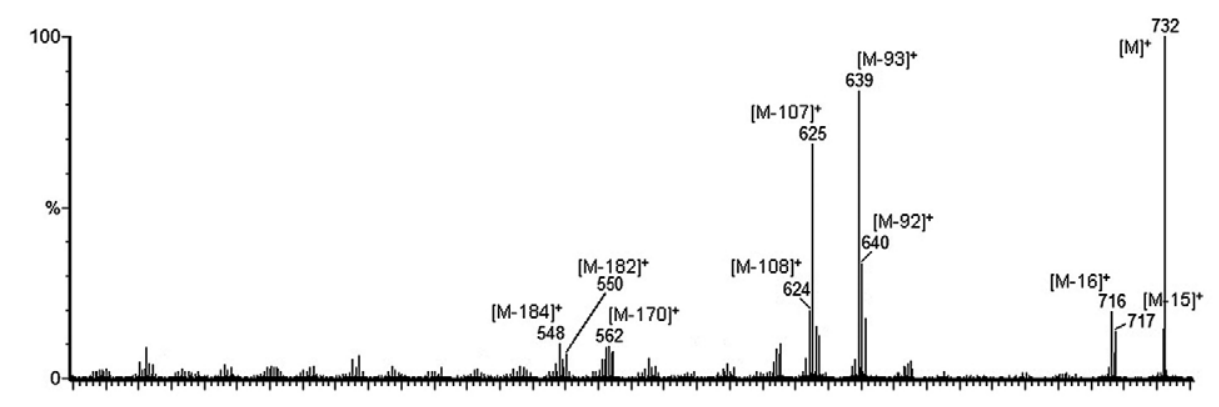

(a)

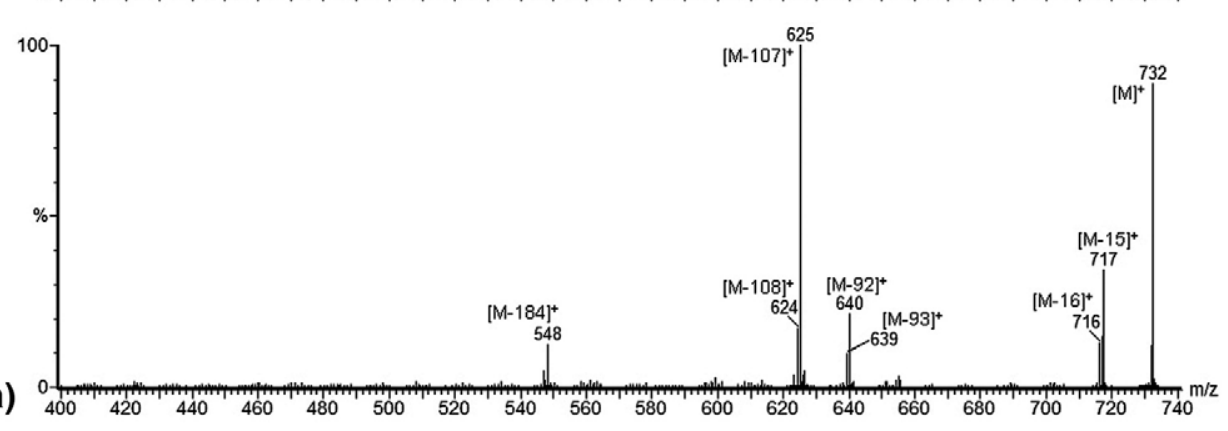

(b)
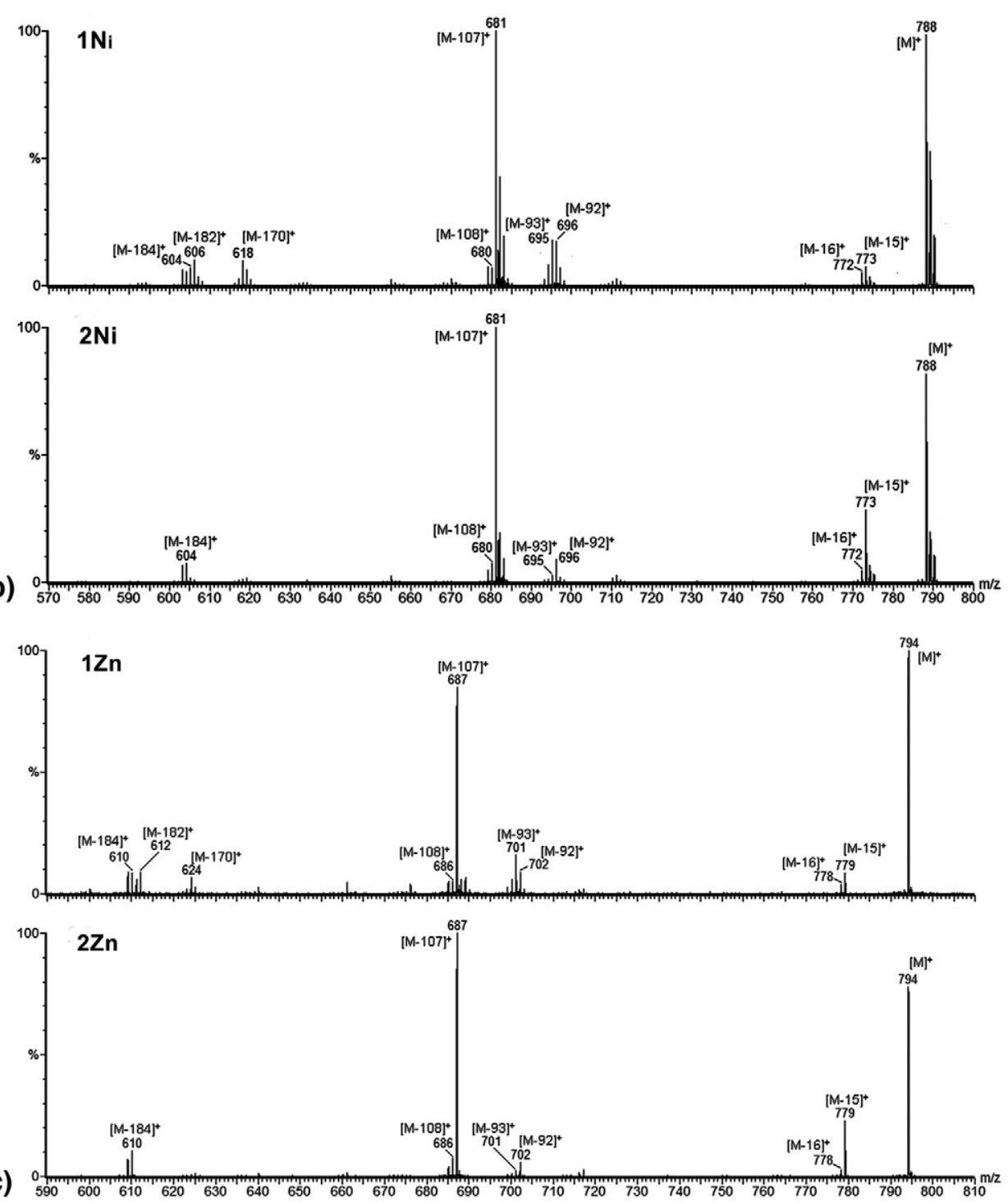

Figure 1. (a) Product ion spectra of the $\mathrm{M}^{+}$ions of Compounds 1 and 2. (b) Product ion spectra of the $\mathrm{M}^{+}$ions of Compounds $\mathbf{1 N i}$ and 2Ni. (c) Product ion spectra of the $\mathrm{M}^{+}$ions of Compounds $1 \mathrm{Zn}$ and $2 Z n$. 
Table 2. Dihedral angles relative to the $\beta$-pyrrolic vinyl substituent

\begin{tabular}{lccc}
\hline & \multicolumn{3}{c}{ Dihedral angles } \\
\cline { 2 - 4 } & $\mathrm{C} 1-\mathrm{C} 2-\mathrm{C} 1^{\prime}-\mathrm{C} 2^{\prime}$ & $\mathrm{C} 20-\mathrm{C} 1-\mathrm{C} 2-\mathrm{C} 1^{\prime}$ & $\mathrm{C}^{\prime}{ }^{\prime}-\mathrm{C} 2^{\prime}-\mathrm{C} 1^{\prime \prime}-\mathrm{C} 6^{\prime \prime}$ \\
\hline \hline 1 & 38.2 & 16.7 & 2.5 \\
2 & 36.0 & 17.1 & 0.2 \\
$1 \mathrm{Zn}$ & 21.8 & 22.6 & 4.4 \\
$2 \mathrm{Zn}$ & 20.5 & 23.5 & 0.9 \\
\hline
\end{tabular}

nominal resolution of 9000 (50\% valley). The spectra were acquired for a range of cone voltages ( 30 to $110 \mathrm{~V}$ ) to obtain good signal-to-noise ratio, either for the precursor or for the fragment ions of interest. Nitrogen was used as nebulizer gas and argon as the collision gas. The samples were dissolved in chloroform and methanol was used as the eluent. For the deuterated compounds, deuterated chloroform $\left(\mathrm{CD}_{3} \mathrm{Cl}\right)$ and deuterated methanol $\left(\mathrm{CD}_{3} \mathrm{OD}\right)$ were used instead. The samples were introduced at a flow rate of $10 \mu \mathrm{L} \mathrm{min}{ }^{-1}$.

Collision induced MS/MS spectra were obtained by selecting the ion of interest with the quadrupole analyzer and using the hexapole collision cell for a range of collision energies (20 to $75 \mathrm{eV}$ ).

All semiempirical calculations carried out in this work $^{\circ}$ used $^{\circ}$ the ${ }^{\circ}$ GAMESS $^{\circ}$ package $e^{\circ}[18]^{\circ}$ and $^{\circ}$ were ${ }^{\circ}$ performed ${ }^{\circ} a^{\circ}{ }^{\circ}$ the ${ }^{\circ} \mathrm{PM}^{\circ}{ }^{\circ}$ level ${ }^{\circ}[19]{ }^{\circ}{ }^{\circ}$ Prior $^{\circ}$ assessment ${ }^{\circ}$ of ${ }^{\circ}$ the general structure of the molecule employed the TINKER $^{\circ}[20]^{\circ}$ set $^{\circ}$ of $^{\circ}$ programs.

\section{Results and Discussion}

\section{Mass Spectra}

At low cone voltages, mainly the intact cations $\mathrm{M}^{+}$are observed for both the nondeuterated and deuterated compounds. In Table 1 , the monoisotopic masses for the $\mathrm{M}^{+}$cations of all the compounds are shown.

As the cone voltage increases (values above $50 \mathrm{~V}$ ), fragment ions such as $[\mathrm{M}-15]^{+},[\mathrm{M}-16]^{+},[\mathrm{M}-92]^{+}$, $[\mathrm{M}-93]^{+}$, and $[\mathrm{M}-107]^{+}$are observed for the nondeuterated compounds and the corresponding $[\mathrm{M}$ $-18]^{+},[\mathrm{M}-19]^{+},[\mathrm{M}-95]^{+},[\mathrm{M}-96]^{+}$, and $[\mathrm{M}-$ $110]^{+}$ions for the deuterated compounds. In general, the deuterated compounds present a higher degree of fragmentation.

In the same experimental conditions, the base peaks for all the compounds correspond to the $[\mathrm{M}-107]^{+}$ ions for the nondeuterated compounds and $[\mathrm{M}-110]^{+}$ for the deuterated compounds, with the exception of the free-base 1 and its deuterated counterpart 1D. For these compounds, 1 and $1 \mathrm{D}$, the base peaks correspond to the $[\mathrm{M}-93]^{+}$and $[\mathrm{M}-96]^{+}$ions, respectively.

\section{Product Ion Spectra}

Product ion spectra were obtained for all the $\mathrm{M}^{+}$ions and for the most significant fragment ions such as the $[\mathrm{M}-15]^{+},[\mathrm{M}-16]^{+},[\mathrm{M}-92]^{+},[\mathrm{M}-93]^{+}$, and $[\mathrm{M}-$ $107]^{+}$ions, and also for the corresponding ions of their deuterated counterparts. The product ion spectra of the $\mathrm{M}^{+}$ions for Compounds $1,1 \mathrm{Ni}, 1 \mathrm{Zn}, 2,2 \mathrm{Ni}, \mathbf{2 Z n}$, and their deuterated counterparts are similar to their mass spectra obtained at higher cone voltages.

In the same experimental conditions, the base peaks for the product ion spectra of the $\mathrm{M}^{+}$ions of all the compounds, with the exception of Compound 1 and 1D, correspond to the $[\mathrm{M}-107]^{+}$(and $[\mathrm{M}-110]^{+}$) ions. For Compounds $\mathbf{1}$ and $\mathbf{1 D}$, the most abundant fragment ion are the $[\mathrm{M}-93]^{+}$, and $[\mathrm{M}-96]^{+}$ions, respectively.

The product spectra of the $\mathrm{M}^{+}$ions of all the nondeuterated compounds (cone voltages of $50 \mathrm{~V}$ and collision ${ }^{\circ}$ energies ${ }^{\circ}$ of $\left.^{\circ} 50^{\circ} \mathrm{eV}\right)^{\circ}$ are $^{\circ}$ shown $^{\circ}$ in $^{\circ}{ }^{\circ}$ Figure $^{\circ} 1 \mathrm{a},{ }^{\circ} \mathrm{b}$, and $\mathrm{c}$, and the $\mathrm{m} / \mathrm{z}$ values and relative abundances of the main $^{\circ}$ fragment ${ }^{\circ}$ ions $^{\circ}$ are $^{\circ}$ shown $^{\circ}$ in $^{\circ}$ Table $^{\circ} 2 .^{\circ} \mathrm{As}^{\circ}$ can $^{\circ}$ be seen, with the exception of Compound 1 , the more abundant fragment ions are formed by losses of $107 \mathrm{Da}$. For Compound 1, the most abundant ion corresponds to a loss of $93 \mathrm{Da}$.

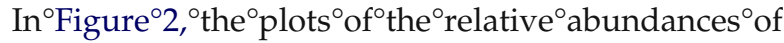
the main fragment ions of the precursor $\mathrm{M}^{+}$ions for all the nondeuterated compounds are shown, and it is evident that the relative abundances of all the fragment ions for all the compounds follow a broad general pattern, with the exception of Compound 1.

When we compare the product ion spectrum of the $\mathrm{M}^{+}$ion of a deuterated compound with the product ion spectrum of the $\mathrm{M}^{+}$ion of its nondeuterated counter-

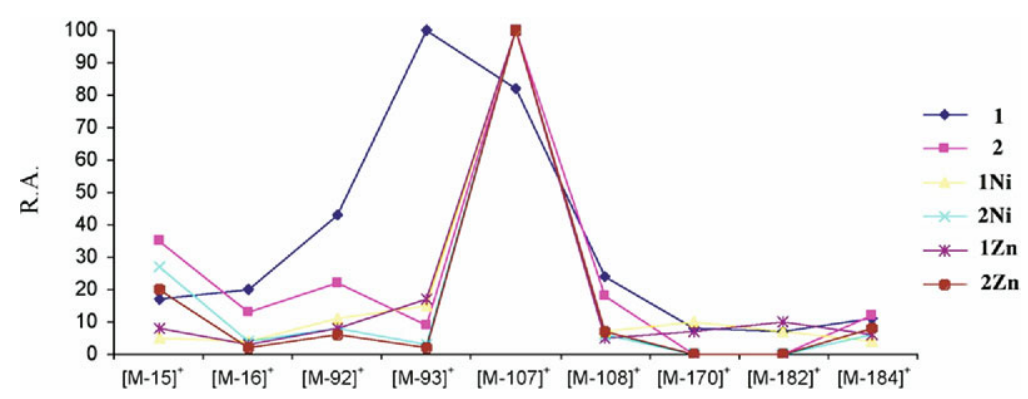

Figure 2. Fragment ions and relative abundances of the $\mathrm{M}^{+}$precursor ions for Compounds $\mathbf{1}, \mathbf{2}, \mathbf{1 N i}$, $2 \mathrm{Ni}, 1 \mathrm{Zn}$, and $2 \mathrm{Zn}$. 


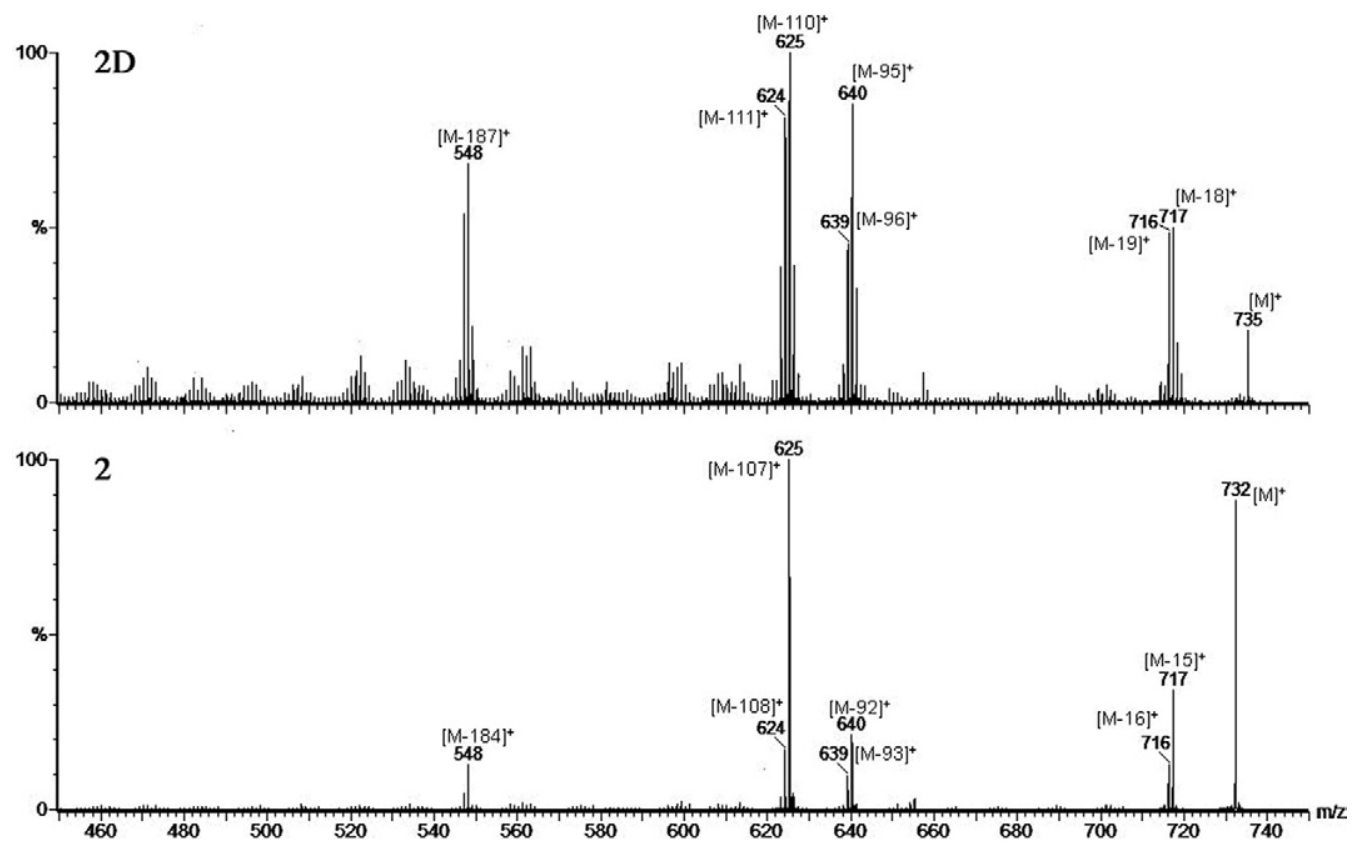

Figure 3. Product ion spectra of the $\mathrm{M}^{+}$ions of Compounds $2 \mathrm{D}$ and 2.

part, obtained in the same experimental conditions, we can observe that the fragment ions are more abundant for the deuterated compound and that the fragmentation is more widespread. This is a feature common to all deuterated compounds and is probably because the $\mathrm{M}^{+}$ ions of the deuterated compounds are formed with higher internal energies than the homologous ions of the ${ }^{\circ}$ nondeuterated ${ }^{\circ} \mathrm{Compounds} .{ }^{\circ} \mathrm{As} \mathrm{s}^{\circ} \mathrm{an}^{\circ} \mathrm{example},{ }^{\circ} \mathrm{in}^{\circ} \mathrm{Fig}$ - ure $^{\circ} 3^{\circ}$ the ${ }^{\circ}$ product $^{\circ}{ }^{\circ}{ }^{\circ}{ }^{\circ}$ spectra ${ }^{\circ}$ of ${ }^{\circ}$ the ${ }^{\circ} \mathrm{M}^{+^{\circ}}$ ions $^{\circ}$ of ${ }^{\circ} \mathrm{Com}^{-}$ pounds $2 \mathrm{D}$ and $\mathbf{2}$ in the same experimental conditions (cone voltages of $50 \mathrm{~V}$ and collision energies of $50 \mathrm{eV}$ ) are shown, and as can be seen the abundance of the precursor ion for the nondeuterated Compound 2 is approximately four times the abundance of the homologous ion for the deuterated Compound 2D.

All the $[\mathrm{M}-107]^{+}$ions are very abundant, even in the



Figure 4. Product ion spectra of the $\mathrm{M}^{+}=[\mathrm{M}-107]^{+}$ions for Compounds 2, 2Ni, and 1Zn. 


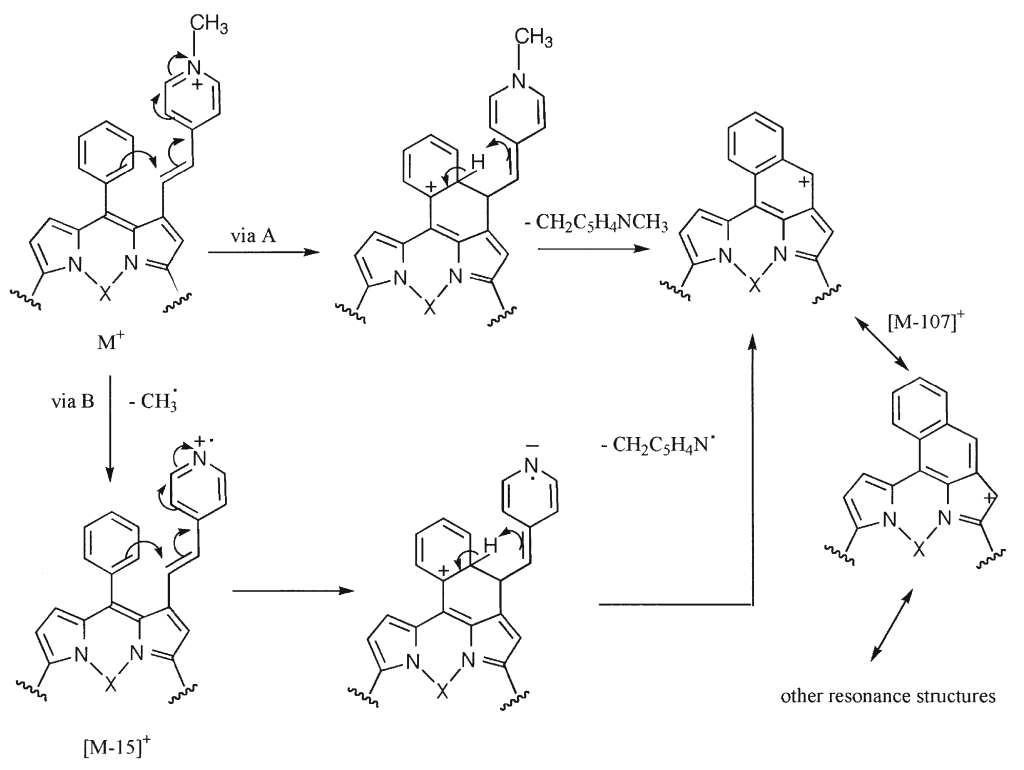

Scheme 2

case of Compound 1 where the base peak corresponds to the $[\mathrm{M}-93]^{+}$ion. The product ion spectra of the $[\mathrm{M}-$ $107]^{+}=\mathrm{M}^{+}$ions for Compounds 2 (free-base), $2 \mathrm{Ni}$ (nickel complex), and Compound 1Zn (zinc complex) are shown ${ }^{\circ}$ in $^{\circ}$ Figure $^{\circ} 4^{\circ}\left(\right.$ cone $^{\circ}$ voltages $^{\circ}$ of ${ }^{\circ} 80^{\circ} \mathrm{V}^{\circ}$ and ${ }^{\circ}$ collision energies of $50 \mathrm{eV}$ ). The spectra are very similar, especially the spectra of the metallated Compounds $1 \mathrm{Zn}$ and $2 \mathrm{Ni}$.

\section{Fragmentation Mechanisms}

The loss of 107 (110) Da from all the $\mathrm{M}^{+}$ions may occur through a rearrangement involving cyclization with migration of a hydrogen from an ortho position of the phenyl substituent closest to the $\beta$-pyrrolic substituent, with a subsequent fission of the $\mathrm{C} 1^{\prime}-\mathrm{C} 2^{\prime}$ alkene bond (see Scheme 1) and elimination of the neutral species $\mathrm{CH}_{2} \mathrm{C}_{5} \mathrm{H}_{4} \mathrm{NCH}_{3}\left(\mathrm{CH}_{2} \mathrm{C}_{5} \mathrm{H}_{4} \mathrm{NCD}_{3}\right.$ ) (see Scheme 2, via $\mathrm{A}$ ).

Another possible mechanism for the formation of the $[\mathrm{M}-107]^{+}\left([\mathrm{M}-110]^{+}\right.$for the deuterated compounds $)$ ions is presented in Scheme 2, via $B$. This alternative mechanism is based on the loss of $92 \mathrm{Da}$ observed in the product ion spectra of the $[\mathrm{M}-15]^{+}\left([\mathrm{M}-18]^{+}\right.$for the deuterated compounds) ions.

The structure proposed for the $[\mathrm{M}-107]^{+}$ion is planar and the charge delocalized throughout the macrocycle. Cyclization with formation of six-membered rings was previously proposed for neutral $\beta$-substituted meso-tetraphenylporphyrins ${ }^{\circ}[21]$.

The fragments corresponding to losses of 184 (187) Da may be formed by a subsequent loss from the [M -

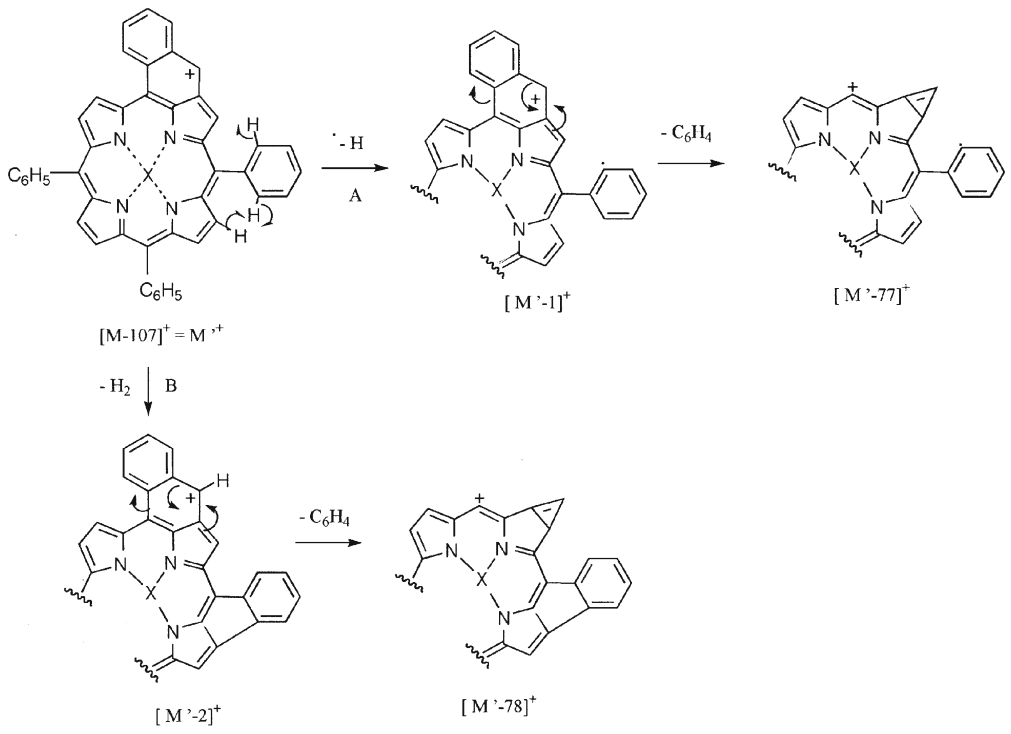

Scheme 3 


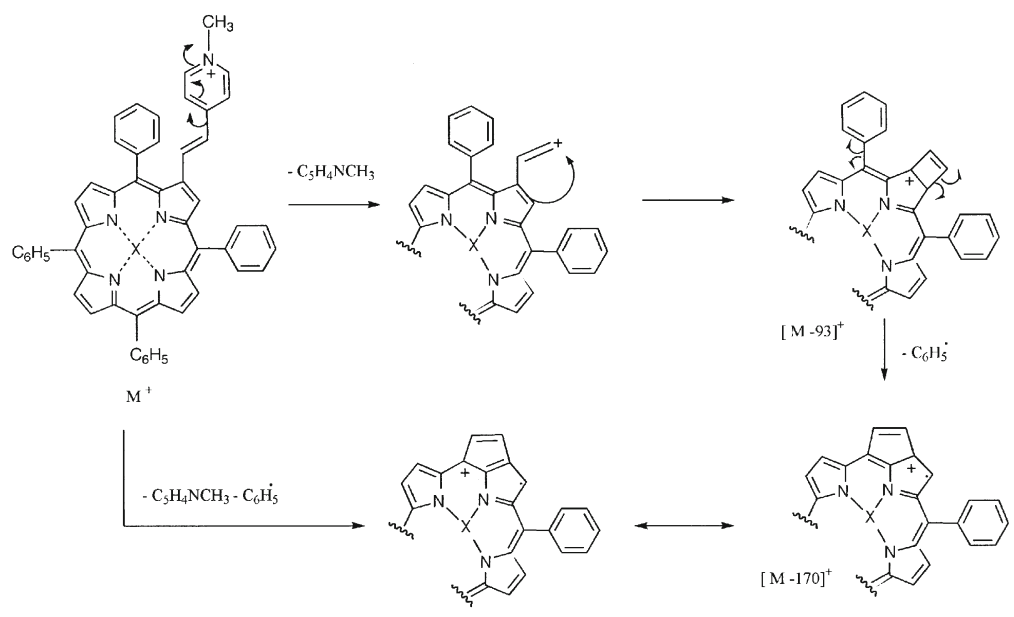

Scheme 4

$107]^{+}\left([\mathrm{M}-110]^{+}\right)$ions, as shown in Scheme 3. In the case of the loss of $\mathrm{H}_{2}$, a similar cyclization with elimination of an HF molecule and formation of a fivemembered ring was described for pyrrolidine-fused cationic $^{\circ}$ chlorins $^{\circ}$ and $^{\circ}$ isobacteriochlorins ${ }^{\circ}[22],{ }^{\circ}$ and $^{\circ}$ for meso-tetrakis(heptafluoropropyl)porphyrin ${ }^{\circ}[13]$.

The fragment ions $[\mathrm{M}-93]^{+}\left([\mathrm{M}-96]^{+}\right)$may be formed, for all the compounds, by loss of the methylpyridyl moiety, as shown in Scheme 4. The ions formed by an overall loss of 170 (173) Da, are observed only for the compounds with an ortho methylpyridyl group and result from a joint loss of methylpyridyl group and a phenyl radical. However, the product ion spectra of all the $[\mathrm{M}-93]^{+}\left([\mathrm{M}-96]^{+}\right)$ions show ions formed by losses of $77 \mathrm{Da}$.

The fragments corresponding to losses of 92 (and 95) Da could be formed by a joint loss of 15 (18) Da from the $\mathrm{N}$-methyl group and $77 \mathrm{Da}$ from a meso-phenyl radical. Fragments formed by loss of 15 and 16 (18 and 19) Da are also observed for all the compounds, the $[\mathrm{M}-15]^{+}$ $\left([\mathrm{M}-18]^{+}\right)$fragment ions being more abundant for the 4-pyridyl compounds. The formation of the $[\mathrm{M}-16]^{+}$ $\left([\mathrm{M}-19]^{+}\right)$may occur by the loss of the $N$-methyl group and one hydrogen from the macrocycle or from the substituents. The fact that the product ion spectra of all the $[\mathrm{M}-15]^{+}\left([\mathrm{M}-18]^{+}\right)$ions show a loss of $1 \mathrm{Da}$ reinforces this hypothesis.

\section{Semiempirical Calculations}

The different behavior of Compound $\mathbf{1}$ (and 1D) may be related to different stereochemistry and/or variation of electronic density within the molecule. It is known that tetrapyrrolic macrocycles may be nonplanar. Conformationally distorted porphyrins have been the subject of interest since it was apparent that heme proteins presented $^{\circ}$ mostly $^{\circ}$ nonplanar ${ }^{\circ}$ heme $^{\circ}$ configurations $^{\circ}\left[23,{ }^{\circ} 24\right]$. The nonplanarity of several porphyrin type chromophores is thought to be related to their functions in natural ${ }^{\circ}$ systems ${ }^{\circ}\left[16,{ }^{\circ} 17\right] .{ }^{\circ}$ The $e^{\circ}$ nonplanarity ${ }^{\circ}$ of ${ }^{\circ}$ the ${ }^{\circ}$ porphyrin core is dependent on the electronic and steric effects of meso and $\beta$-pyrrolic substituents and by the size and type of $^{\circ}$ the ${ }^{\circ}$ metal $^{\circ}$ centers $^{\circ}[25-28]$.

Semiempirical calculations of structural and electronic parameters were also undertaken for Compounds 1, 2, 1Zn, and 2Zn. The dihedral angles for Compounds 1, 2, 1Zn, and 2Zn associated with the $\beta$-pyrrolic vinyl substituent (see Scheme 1 ) are shown in Table 2 .

The dihedral ${ }^{\circ}$ angles shown in ${ }^{\circ}$ Table $2^{\circ}$ displaya9marked difference between what is found for the free-bases $\mathbf{1}$ and 2 and their counterparts in the zinc complexes, in the case of C1-C2-C1'-C2' and C20-C1-C2-C1' angles. In contrast, for angle $\mathrm{C}^{\prime}-\mathrm{C} 2^{\prime}-\mathrm{C} 1^{\prime \prime}-\mathrm{C} 6^{\prime \prime}$ the more significant differences are found for the 2- and 4-pyridyl isomers, irrespective of

Table 3. Electronic charges on the carbon atoms of the $\beta$-pyrrolic vinylpyridyl substituents

$$
\text { Electronic charge }
$$

\begin{tabular}{lrrrr}
\hline & \multicolumn{3}{c}{ Compounds } \\
\cline { 2 - 5 } Atom & $\mathbf{1}$ & \multicolumn{1}{c}{$\mathbf{2}$} & $\mathbf{1 Z n}$ & $\mathbf{2 Z n}$ \\
\hline \hline C2 & $-0,1437$ & $-0,1333$ & $-0,2343$ & $-0,2251$ \\
C1 & $-0,1234$ & $-0,1261$ & $-0,0699$ & $-0,0743$ \\
C20 & 0,1840 & 0,1923 & 0,0442 & 0,0641 \\
C1 $^{\prime}$ & 0,1361 & 0,1208 & 0,1859 & 0,1723 \\
C2 $^{\prime}$ & $-0,2692$ & $-0,2397$ & $-0,2951$ \\
C1" $^{\prime \prime}$ & $-0,0187$ & 0,1282 & 0,0174 & 0,1478 \\
C6" $^{\prime \prime}$ & $-0,1243$ & $-0,1273$ & $-0,1464$ & $-0,1567$ \\
\hline
\end{tabular}


the presence of zinc. These results show that no conformational differences between the isomers were found that can be related to their gas-phase behavior.

The $^{\circ}$ data $^{\circ}$ in $^{\circ}$ Table $^{\circ} 3,{ }^{\circ}$ in $^{\circ}$ turn, ${ }^{\circ}$ indicate ${ }^{\circ} a^{\circ}$ significant variation of the charge in the carbon atom $\mathrm{C} 1$. In fact, there is a clear trend relating this charge with the relative abundances of the $[\mathrm{M}-93]^{+}$ions. Thus, for the negative value of charge assigned to this atom, the relative abundance amounts to $100 \%$ (Compound 1). As the electron density is reduced, the relative abundance is also reduced, first steeply, Compounds $\mathbf{1}$ to $\mathbf{1 Z n}$, and then more gradually, ${ }^{\circ} \mathbf{Z n}$ to ${ }^{\circ} 2$ and $^{\circ} 2$ to ${ }^{\circ} \mathbf{Z n}$ (see ${ }^{\circ}$ Figure $^{\circ} 2^{\circ}$ and $^{\circ} \mathrm{Table}^{\circ} 3$ ). Thus, a negative charge on C1" will facilitate the fission of the $\mathrm{C}^{\prime}-\mathrm{C} 1^{\prime \prime}$ bond for Compound $\mathbf{1}$ with predominant elimination of the $N$-methylpyridyl substituent. Moreover, the presence of negative charge density on $\mathrm{C}^{\prime \prime}$ for the free-based 2-pyridyl compound will enhance the positive charge on the neighboring nitrogen atom.

Systematic studies on virus molecular features, necessary for the understanding of their interaction with photosensitizers, are much less abundant than the same type of studies carried out with bacteria, however, it is known that lipid enveloped viruses such as the Herpes simplex virus are more susceptible to in vitro photodynamic inactivation ${ }^{\circ} \operatorname{than}^{\circ}$ nonenveloped ${ }^{\circ}$ ones $^{\circ}[4]$. Similar $^{\circ}$ to $^{\circ}$ what occurs for bacteria, where the charge distribution on the photosensitizers is important for the interaction with the outer $^{\circ}$ membranes $^{\circ}[4]^{\circ}$, possibly, $^{\circ}$ in $^{\circ}$ the ${ }^{\circ}$ present $^{\circ}$ case $^{\circ}$ the difference in the electron density distribution responsible for the different gas-phase behavior of Compound $\mathbf{1}$ may account for a better interaction with the outer virus envelope.

\section{Conclusions}

The two free-base isomers $\mathbf{1}$ and $\mathbf{2}$ are easily differentiated by ESI-MS/MS, whereas the presence of a metallic center renders differentiation by the same technique much less effective. Local distortion due to the presence of the $\beta$-vinylpyridyl substituent does occur but it does not explain satisfactorily the different gas-phase behavior of the free-base porphyrin; however, differences in electron density distribution can account for the observed gasphase behavior of this virus photoinactivator.

\section{References}

1. Pandey, R. K.; Zheng, G. Porphyrins as Photosensitizers in Photodynamic Therapy. In The Porphyrin Handbook, Vol. VI; Kadish, K. M.; Smith, K. M.; Guilard R., Eds.; Academic Press: San Diego, CA, 2000; p 158.

2. Bonnett, R. Chemical Aspects of Photodynamic Therapy; Gordon and Breach Science Publishers: London, 2000.

3. Wainwright, M. Photodynamic Antimicrobial Chemotherapy (PACT). J. Antimicrob. Chemother. 1998, 42, 13-28.

4. Hamblin, M. R.; Hasan, T. Photodynamic Therapy: A New Antimicrobial Approach to Infectious Disease? Photochem. Photobiol. Sci. 2004, 3, $436-450$.

5. Pinna, A. D.; Rakela, J.; Demetris, A. J.; Fung, J. J. Five Cases of Fulminant Hepatitis Due to Herpes simplex Virus in Adults. Dig. Dis. Sci. 2002, 47, 750-754.

6. Silva, E. M. P.; Giuntini, F.; Faustino, M. A. F.; Tomé, J. P. C.; Neves, M. G. P. M. S.; Tomé, A. C.; Silva, A. M. S.; Santana-Marques, M. G.;
Ferrer-Correia, A. J.; Cavaleiro J. A. S.; Caeiro, M. F.; Duarte, R. R.; Tavares, S. A. P.; Pegado, I. N.; d'Almeida, B.; De Matos, A. P. A. Valdeira, M. L. Synthesis of Cationic $\beta$-Vinyl Substituted meso-Tetraphenylporphyrins and Their in Vitro Activity against Herpes simplex Virus Type 1. Bioorg. Med. Chem. Lett. 2005, 15, 3333-3337.

7. Van Berkel, G. J.; McLuckey S.A.; Glish, G. L. Electrospray Ionization of Porphyrins Using a Quadrupole Ion Trap for Mass Analysis. Anal. Chem. 1991, 63, 1098-1109.

8. Vandell, V. E.; Limbach, P. A. Electrospray Ionization Mass Spectrometry of Metalloporphyrins. J. Mass Spectrom. 1998, 33, 212-220.

9. Witowska-Jarosz, J.; Gorski, L.; Malinowska, E.; Jarosz, M. Mass Spectrometric Investigation of Gallium and Zirconium Complexes with Octaethylporphyrin and Tetraphenylporphyrin. J. Mass Spectrom. 2002, 37, 1236-1241; (b) Witowska-Jarosz, J.; Gorski, L.; Malinowska, E.; Jarosz, M. Electrospray Mass Spectrometric Investigation of the Influence of the Nature of Mobile Phase on the Ionization of Gallium and Zirconium Porphyrins. J. Mass Spectrom. 2003, 38, 1265-1266.

10. Batinic-Haberle, I.; Stevens, R. D.; Fridovich, I. Electrospray Mass Spectrometry of Isomeric Tetrakis( $N$-alkylpyridyl)porphyrins and Their Manganese(III) Complexes. J. Porphyrins Phthalocyanines 2000, 4, 217-227.

11. Kachadourian, R.; Srinivasan, N.; Haney, C. A.; Stevens, R. D. An LDI-TOF and ESI Mass Spectrometry Study of a Series of $\beta$-Substituted Cationic Metalloporphyrins. J. Porphyrins Phthalocyanines 2001, 5, 507-511.

12. Silva, E. M. P.; Domingues, M. R. M.; Barros, C.; Faustino, M. A. F. Tomé, J. P. C.; Neves, M. G. P. M. S.; Tomé, A. C.; Santana-Marques, M. G.; Cavaleiro, J. A. S.; Ferrer-Correia, A. J. Characterization of Dinitroporphyrin Zinc Complexes by Electrospray Ionization Tandem Mass Spectrometry. Unusual Fragmentations of $\beta$-(1,3-Dinitroalkyl)Porphyrins. J. Mass Spectrom. 2005, 40, 117-122.

13. Lau, K. S. F.; Sadilek, M.; Khalil, G. E.; Gouterman, M.; Bruckner, C. Electrospray Ionization (ESI) Tandem Mass Spectrometric Analysis of meso-Tetrakis(Heptafluoropropyl)Porphyrin. J. Am. Soc. Mass Spectrom. 2005, 16, 1915-1920.

14. Senge, M. O. Exercises in Molecular Gymnastics-Bending, Stretching, and Twisting Porphyrins. Chem. Commun. 2006, 3, 9725-9742.

15. Gruden, M.; Grubišić, S.; Coutselos, A. G.; Niketić, S. R. Conformational Analysis of Octa- and Tetrahalogenated Tetraphenylporphyrins and Their Metal Derivatives. J. Mol. Struct. 2001, 595, 209-224.

16. Michel, H.; Epp, O.; Deisenhofer, J. Pigment-Protein Interactions in the Photosynthetic Reaction Center from Rhodopseudomonas viridis. EMBO J. 1986, 5, 2445-2451.

17. Barkigia, K. M.; Chantranupong, L.; Smith, K. M.; Fajer, J. Structural and Theoretical Models of Photosynthetic Chromophores. Implications for Redox, Light Absorption Properties, and Vectorial Electron Flow. J. Am. Chem. Soc. 1988, 110, 7566-7567.

18. Schmidt, M. W.; Baldridge, K. K.; Boatz, J. A.; Elbert, S. T.; Gordon, M. Jensen, J. H.; Koseki, S.; Matsunaga, N.; Nguyen, K. A.; Su, S. J.; Windus, T. L.; Dupuis, M.; Montgomery, J. A. General Atomic and Molecular Electronic Structure System. J. Comput. Chem. 1993, 14, 1347-1363.

19. Stewart, J. J. P. Optimization Parameters for Semiempirical Methods. II. Applications. J. Comput. Chem. 1989, 10, 221-264.

20. Pappu, R. V.; Hart, R. K.; Ponder, J. W. Analysis and Application of Potential Energy Smoothing and Search Methods for Global Optimization. J. Phys. Chem. B 1998, 102, 9725-9742.

21. Domingues, M. R. M.; Marques, M. G. O. S.; Alonso, C. M. A.; Neves, M. G. P. M. S.; Cavaleiro, J. A. S.; Ferrer-Correia, A. J.; Nemirovskiy, O. V.; Gross, M. L. Unexpected Fragmentation of $\beta$-Substituted mesoTetraphenylporphyrins Induced by High-Energy Collisional Activation. J. Am. Soc. Mass Spectrom. 2002, 13, 1427-1431.

22. Izquierdo, R. A.; Barros, C. M.; Santana-Marques M. G.; Ferrer-Correia, A. J.; Silva, A. M. G.; Tomé, A. C.; Silva, A.; Neves M. G. P. M. S.; Cavaleiro, J. A. S. Cycloreversion and Other Gas-Phase Reactions of Neutral and Cationic Pyrrolidine-Fused Chlorins and Isobacteriochlorins Under Ion Bombardment and Electrospray. Rapid Commun. Mass Spectrom. 2004, 18, 2601-2611.

23. Fermi, G.; Perutz, J. F.; Shaanan, B.; Fourne, R. The Crystal Structure of Human Deoxyhemoglobin at 1.74 A Resolution. J. Mol. Biol. 1984, 175, 159-174.

24. Finzel, B. C.; Poulos, T. L.; Kraut. J. Crystal Structure of Yeast Cytochrome $c$ Peroxidase Refined at $1.7 \AA$ A Resolution. J. Biol. Chem. 1984, 259, 3027-3036.

25. Senge, M. Highly Substituted Porphyrins. In The Porphyrin Handbook, Vol. I; Kadish, K. M.; Smith, K. M.; Guilard R., Eds.; Academic Press: San Diego, CA, 2000; p 239.

26. Barkigia, K. M.; Berber, M. D.; Fajer, J. C.; Medforth, J.; Renner, M. W. Smith, K. M. Nonplanar Porphyrins. X-Ray Structures of $(2,3,7,8,12,13$, 17,18-Octaethyl-5,10,15,20-Tetraphenylporphinato)Zinc(II) and (2,3,7,8,12, 13,17,18-Octamethyl-5,10,15,20-Tetraphenylporphinato)Zinc(II). J. Am. Chem. Soc. 1990, 112, 8851-8857.

27. Medforth, C. J.; Smith, K. M. The Synthesis and Solution Conformation of Dodecaphenylporphyrin. Tetrahedron Lett. 1990, 31, 3719-3722.

28. Peixoto, A. F.; Pereira, M. M.; Sousa, A. F.; Pais, A. A. C. C.; Neves, M. G. P. M. S.; Silva, A. M. S.; Cavaleiro, J. A. S. Improving Regioselectivity in the Rhodium Catalyzed Hydroformylation of Protoporphyrin-IX and Chlorophyll a Derivatives. J. Mol. Catal. A Chem. 2005, 235, 185-193. 